\title{
Review \\ Host-Adapted Gene Families Involved in Murine Cytomegalovirus Immune Evasion
}

\author{
Sara Becker (D), Annette Fink, Jürgen Podlech, Matthias J. Reddehase * and Niels A. Lemmermann (D)
}

Citation: Becker, S.; Fink, A.; Podlech, J.; Reddehase, M.J.; Lemmermann, N.A. Host-Adapted Gene Families Involved in Murine Cytomegalovirus Immune Evasion. Viruses 2022, 14, 128. https://doi.org/10.3390/ v14010128

Academic Editors: Alessandro Sinigaglia and Luisa Barzon

Received: 17 December 2021

Accepted: 10 January 2022

Published: 11 January 2022

Publisher's Note: MDPI stays neutral with regard to jurisdictional claims in published maps and institutional affiliations.

Copyright: (C) 2022 by the authors. Licensee MDPI, Basel, Switzerland. This article is an open access article distributed under the terms and conditions of the Creative Commons Attribution (CC BY) license (https:// creativecommons.org/licenses/by/ $4.0 /)$.
Institute for Virology and Research Center for Immunotherapy (FZI), University Medical Center of the Johannes Gutenberg-University Mainz, 55131 Mainz, Germany; sarbecke@uni-mainz.de (S.B.); annette.fink82@t-online.de (A.F.); podlech@uni-mainz.de (J.P.); lemmermann@uni-mainz.de (N.A.L.)

* Correspondence: matthias.reddehase@uni-mainz.de

\begin{abstract}
Cytomegaloviruses (CMVs) are host species-specific and have adapted to their respective mammalian hosts during co-evolution. Host-adaptation is reflected by "private genes" that have specialized in mediating virus-host interplay and have no sequence homologs in other CMV species, although biological convergence has led to analogous protein functions. They are mostly organized in gene families evolved by gene duplications and subsequent mutations. The host immune response to infection, both the innate and the adaptive immune response, is a driver of viral evolution, resulting in the acquisition of viral immune evasion proteins encoded by private gene families. As the analysis of the medically relevant human cytomegalovirus by clinical investigation in the infected human host cannot make use of designed virus and host mutagenesis, the mouse model based on murine cytomegalovirus ( $\mathrm{mCMV}$ ) has become a versatile animal model to study basic principles of in vivo virus-host interplay. Focusing on the immune evasion of the adaptive immune response by $\mathrm{CD} 8^{+} \mathrm{T}$ cells, we review here what is known about proteins of two private gene families of $\mathrm{mCMV}$, the $\mathrm{m02}$ and the $m 145$ families, specifically the role of $m 04, m 06$, and $m 152$ in viral antigen presentation during acute and latent infection.
\end{abstract}

Keywords: adoptive cell transfer; antigen presentation; antiviral protection; CD8 T cells; co-evolution; cytomegalovirus; gene family; immune evasion; latent infection/latency; memory inflation

\section{Introduction}

Human cytomegalovirus (hCMV), the prototype member of the $\beta$-subfamily of the herpes virus family [1], is of medical relevance as it can cause lethal disease resulting from cytopathogenic organ infection in an immunologically immature or immunocompromised human host (for a synopsis of hCMV disease manifestations, see [2,3]). One area of concern and significant public health impact are fetuses infected upon diaplacental transmission of the virus in expectant mothers primarily infected, superinfected, or reactivating latent virus during pregnancy. This congenital infection results in a high risk of developing birth defects with long-term sequelae in survivors, such as sensorineural hearing loss and mental retardation (for reviews, see $[4,5]$ ). In addition, in transplantation centers worldwide, primary or reactivated hCMV is a feared complication in transplantation patients. These include recipients of solid organ transplantation (SOT) who receive immunosuppressive prophylaxis to prevent allograft rejection (for reviews, see [6,7]) as well as recipients of hematopoietic cell transplantation (HCT) who are immunocompromised by hematoablative therapy of an aggressive hematopoietic malignancy prior to HCT and, in particular in the case of unrelated or family donors, by immunosuppressive prophylaxis or therapy of graft-versus-host disease (GvHD) after HCT [8-10]. Graft loss in SOT and an often lethal interstitial pneumonia in HCT are major disease manifestations of hCMV infection. In fact, follow-up monitoring for early detection of hCMV reactivation and controlling the success of antiviral therapy in HCT recipients is a major assigned task of virological laboratory diagnostics at university centers that operate an HCT unit. 
One pathogenetic factor of all CMVs is the evolutionary acquisition of genes that subvert recognition of infected cells by the hosts' intrinsic pathogen sensing mechanisms as well as the innate and adaptive immune response (for reviews, see [11-15]). As a consequence of adaptation to the respective mammalian host during the estimated 350 million years of co-evolution [1], CMV species differ from each other in so-called "private genes". These are defined by the absence of sequence homologs in phylogenetically distant CMV species, except for some overlap between hCMV and the phylogenetically less distant non-human primate CMVs [1]. It appears that duplications and mutations starting from an ancestor gene, supposedly captured from the host early in co-evolution, were the viral evolutionary response to the development of polymorphism of cellular genes involved in host immunity, such as genes encoding antigen-presenting HLA/MHC molecules. This may explain in part why private genes are often organized in gene families, whose corresponding proteins share motifs for cargo sorting and/or are structurally related to host proteins for cellular cargo binding. Gene families involved in immune evasion have been comprehensively reviewed by Berry and colleagues [15]. Specifically, immune evasion proteins of hCMV cluster in gene families (i) US2-US11, sharing an immunoglobulin domain and interfering with MHC class I (MHC-I) cell surface trafficking, (ii) the UL18 family of MHC-I homologs, (iii) the less conserved RL11 family of mostly undefined precise function, and (iv) the US12 family thought to be involved in the regulation of NK cell ligands, adhesion molecules, and cytokine receptors (for greater detail, see $[15,16]$ ).

An in vivo study of hCMV immune evasion by clinical investigation in the human host is limited, because designed mutagenesis of both the virus and the host is prohibited for ethical reasons or is unfeasible. Despite significant genetic differences in both virus and host to always bear in mind, this is the justification for non-primate, usually rodent, CMV models. Ideally, studies in animal models should address questions that cannot be answered by clinical investigation in the human host, such as cooperative or antagonistic effects of immune evasion proteins tested by combinatorial viral gene deletion. As we have reviewed previously, results from the mouse model of infection with murine CMV (mCMV) have revealed basic principles of CMV pathogenesis, immune control, and immune evasion that also apply to human infection, although not in molecular details but by convergence in many aspects of virus-host interaction [17]. It should be recalled that immune evasion of CMVs was first described in the mouse model [18,19].

Here we review what is currently known about members of the mCMV gene families $m 02$ and $m 145$ that localize to opposite ends of the viral genome (Figure 1). Focus is given to the role of proteins encoded by genes $m 04$ and $m 06$ of the $m 02$ gene family and $m 152$ of the $m 145$ gene family in positive and negative regulation of MHC-I trafficking and cell surface presentation of peptide-loaded MHC-I (pMHC-I) molecules for recognition by antivirally protective $\mathrm{CD} 8^{+} \mathrm{T}$ cells during acute and latent infection.

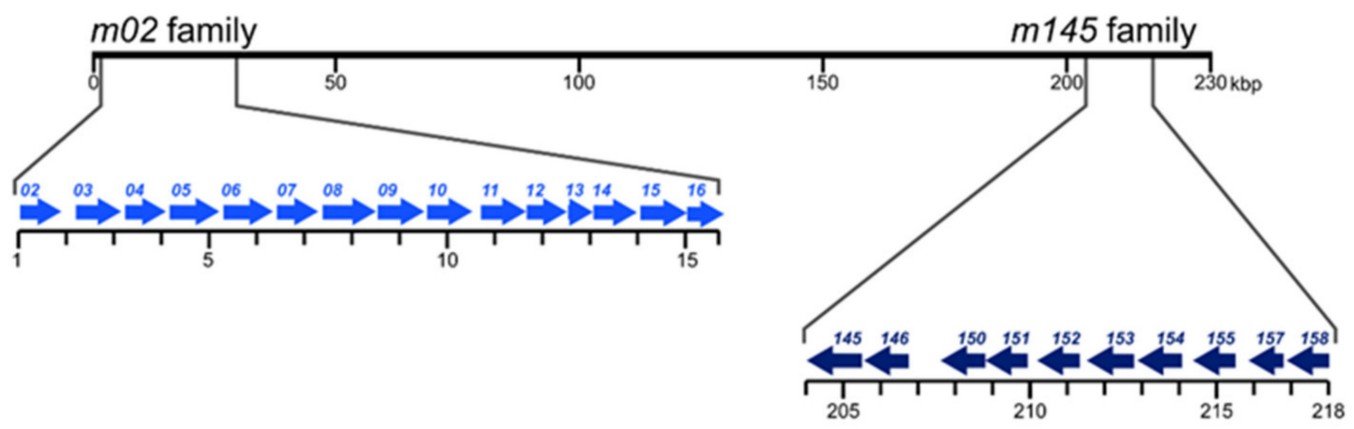

Figure 1. Map positions of mCMV gene families $m 02$ and $m 145$. Arrows indicate the direction of transcription on the coding DNA strand [20,21]. In mCMV gene nomenclature, lower case " $m$ " indicates an absence of homology to hCMV genes. 


\section{The $m 02$ Gene Family}

Known key features of $m 02$ gene family members are compiled in Table 1.

Table 1. Members of the $m 02$ gene family. Experimentally determined molecular masses refer to the most prevalent glycosylated isoforms. (-) not studied or not applicable; (Red) cytoplasmic tail YXX $\Phi$ (where $\Phi$ is a hydrophobic amino acid residue) cargo sorting motif for binding to cellular adapter proteins AP-2 and/or AP-4; (Blue) cytoplasmic tail di-leucine cargo sorting motif [D/E](X)XXXL[L/I] for binding to cellular adapter proteins AP-1 and/or AP-3; (NK) natural killer; (PDB ID) Protein Data Bank identification code; (TCR) T cell receptor; (TMD) transmembrane domain.

\begin{tabular}{|c|c|c|c|c|c|c|c|}
\hline Gene/Protein & $\begin{array}{c}\text { Molecular } \\
\text { Mass }\end{array}$ & $\begin{array}{l}\text { Protein } \\
\text { Structure }\end{array}$ & Sorting Motif & $\begin{array}{l}\text { Binding Partner } \\
\text { (Cargo) }\end{array}$ & $\begin{array}{l}\text { Receptor of Cell } \\
\text { Surface Ligand }\end{array}$ & $\begin{array}{l}\text { Role in } \\
\text { Immunity }\end{array}$ & Ref. \\
\hline m02 & - & - & YRDL & - & - & none found & [22] \\
\hline m03;m03.5 & - & - & none & - & $\begin{array}{c}\text { not identified } \\
\text { Ly49-family }\end{array}$ & - & [23] \\
\hline \multirow[t]{2}{*}{ m04/gp34 } & $34 \mathrm{kDa}$ & $\begin{array}{c}\text { PDB ID 4PN6 } \\
{[24]}\end{array}$ & YRRF & MHC-I & $\begin{array}{l}\text { NK cell receptors } \\
\text { Ly49A, C, G2 }\end{array}$ & NK cell evasion & [25-30] \\
\hline & & & & & TCR & $\begin{array}{c}\text { Presentation of } \\
\text { pMHC-I }\end{array}$ & {$[31,32]$} \\
\hline m05 & - & - & YICL & - & - & - & \\
\hline$m 06 / g p 48$ & $48 \mathrm{kDa}$ & - & EPLARLL & MHC-I & - & $\begin{array}{l}\mathrm{CD}^{+} \mathrm{T} \text { cell } \\
\text { evasion }\end{array}$ & [33-36] \\
\hline$m 07$ & - & - & YGFF & - & - & - & \\
\hline m08 & - & - & YGFL & - & - & - & \\
\hline m09 & - & - & YGFL & - & - & - & \\
\hline$m 10$ & - & - & YGFL & - & - & - & \\
\hline$m 11$ & - & - & none & - & - & - & \\
\hline$m 12$ & $40 \mathrm{kDa}$ & PDB ID 5TZN & YRRRGF & $\begin{array}{l}\text { NKR-P1B and } \\
\text { isoforms }\end{array}$ & $\begin{array}{c}\text { Clr-b } \\
\text { or unknown }\end{array}$ & NK cell evasion & [37] \\
\hline$m 13$ & - & - & none & - & - & - & \\
\hline$m 14$ & - & - & none & - & - & - & \\
\hline m15 locus & - & - & none & - & - & NK cell evasion & [38] \\
\hline$m 16$ & - & - & YAIL & - & - & - & \\
\hline
\end{tabular}

The m02 family members usually represent type-I integral membrane glycoproteins that primarily localize in the endoplasmic reticulum (ER), most of which carry a cargo sorting motif in their C-terminal, cytosolic tail. A canonical YXXФ motif (proteins m02, m04, $\mathrm{m} 05, \mathrm{~m} 07-\mathrm{m} 10$, and $\mathrm{m} 16$ ) can link the protein to heterotetrameric cellular adapter proteins (AP) AP-2 and/or AP-4, whereas a di-leucine motif E(X)XXXLL (protein m06 only) can link the protein to AP-1 and/or AP-3 [39-41]. Although the di-leucine motif in m06 differs from the canonical motif by an additional spacer residue, it has proven functional, based on loss of function after replacing LL with AA $[33,36]$. If the noncanonical tyrosine-based motif in $\mathrm{m} 12$ is functional awaits mutational analysis. Notably, the motifs in m04 and m06 are highly conserved among mCMV isolates/strains sequenced so far, which suggests an important function of these motifs in virus-host co-evolution (Figure 2). 
m04

\section{m06}

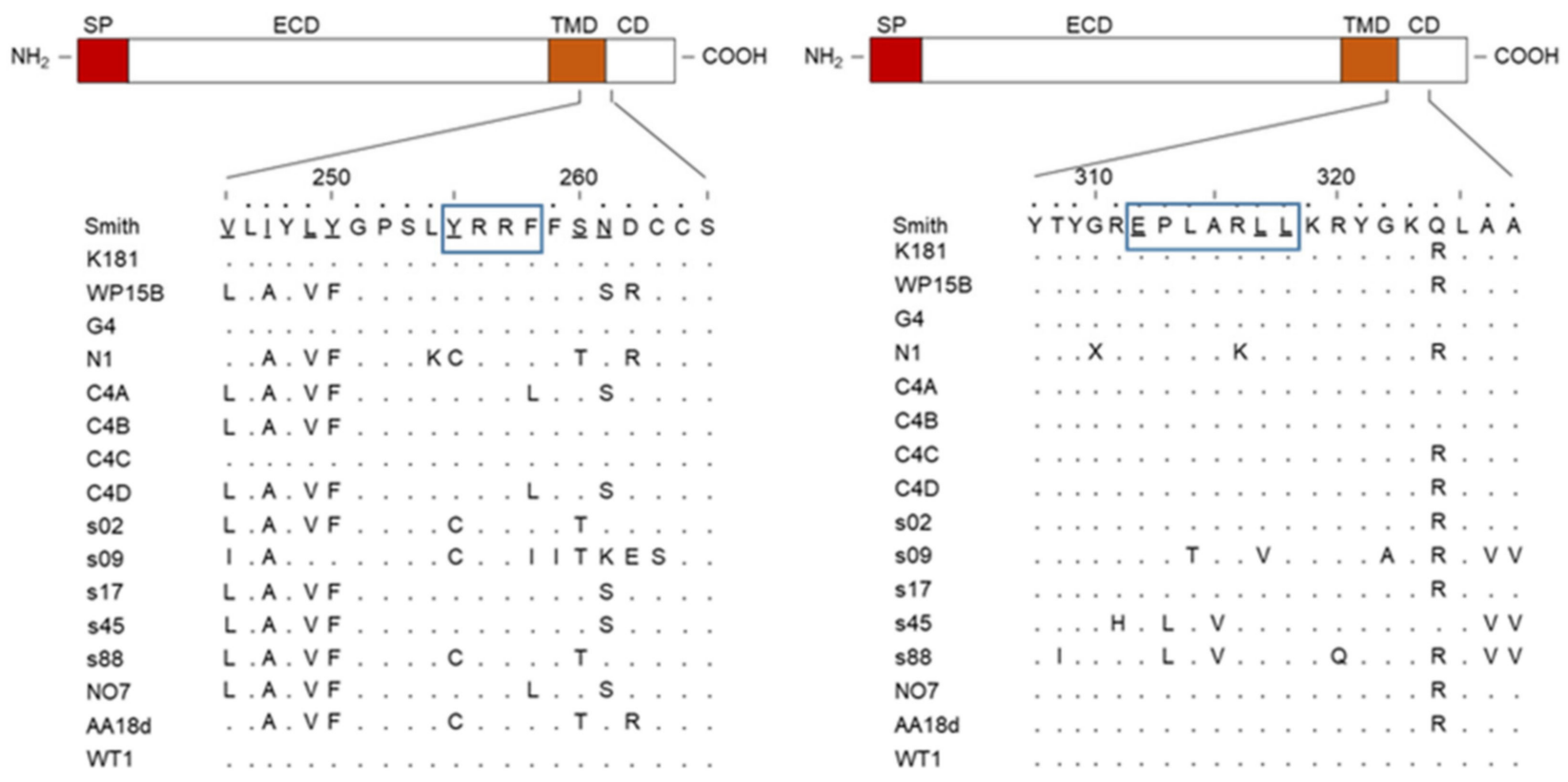

Figure 2. High evolutionary conservation of $m 04$ and $m 06$ cargo sorting motifs in strains of mCMV. (Smith NC_004065 [20], K181 AM886412 [42], WP15B EU579860 [43], G4 EU579859 [43], N1 HE610454 [44], C4A EU579861 [43], C4B HE610452 [44], C4C HE610453 [44], C4D HE610456 [44], s02 MH118557 [45], s09 MH118555 [45], s17 MH118558 [45], s45 MH118556 [45], s88 MG957497 [45], NO7 HE610455 [44], AA18d HE610451 [44], WT1 GU305914 [46]).

Structural analysis of m04 as an m02 family paradigm revealed a shared $\beta$-sandwich immunoglobulin variable (Ig-V)-like fold in the luminal (N-terminal) domains of m04 and m06 to where pMHC-I cargo binds [24,47]. Based on the structural analysis, Berry and colleagues suggested an m04-like fold for all family members except $\mathrm{m} 12$ and $\mathrm{m} 13$ [24]. For m06, NMR-based studies by Sgourakis and colleagues [48] revealed tight binding to pMHC-I $\mathrm{L}^{\mathrm{d}}$ at a discrete site located underneath the peptide-binding platform that partially overlaps with the $\beta 2$-microglobulin interface on the MHC-I heavy chain.

Thus, by binding to pMHC-I in the ER and motif-dependent linking of the complex to the respective cellular APs for cargo sorting, $\mathrm{m} 04$ and $\mathrm{m} 06$ determine the intracellular trafficking and fate of pMHC-I. For the remaining family members $(\mathrm{m} 02, \mathrm{~m} 05, \mathrm{~m} 07-\mathrm{m} 10$, and m16) that also carry YXX $\Phi$ sorting motifs, the cargos have not yet been defined. Theoretically, it could be cargos not involved in innate or adaptive immune responses, though MHC-I molecules of $\mathrm{H}-2$ haplotypes other than those binding to m04 remain candidates. One often tends to forget that virus evolution is driven by adaptation to host evolution and thus must cover MHC polymorphism. Traditionally, studies in the mouse model focus on haplotypes $H-2^{b}$ and $H-2^{d}$, and less often $H-2^{k}$ is studied, whereas other $H-2$ haplotypes are rarely considered. As discussed by Corbett and colleagues [23], high sequence variability of $\mathrm{m} 04$ among $\mathrm{mCMV}$ isolates, except for the conserved endocytic motif (Figure 2), might reflect an adaptation to MHC-I polymorphism. The structural analysis of m04 performed by Berry and colleagues [24] included variants $\mathrm{m}_{04}{ }^{\mathrm{Smith}}, \mathrm{m} 04^{\mathrm{G} 4}$, and $\mathrm{m} 04^{\mathrm{W} 8211}$, and revealed their binding to the MHC-I molecules $\mathrm{D}^{\mathrm{d}}, \mathrm{L}^{\mathrm{d}}$, and $\mathrm{D}^{\mathrm{k}}$. As already shown experimentally in earlier reports, $\mathrm{m} 04^{\text {Smith }}$ binds to $\mathrm{D}^{\mathrm{d}}, \mathrm{L}^{\mathrm{d}}$, and $\mathrm{K}^{\mathrm{b}}$, but not to $\mathrm{K}^{\mathrm{d}}$ [25-27]. It is thus open to question as to which of the many untested MHC-I molecules of other inbred mouse $H-2$ haplotypes or wild-derived mice m04 might bind or fail to bind (for a list of $H-2$ haplotypes and MHC-I alleles, see http:/ / www.imgt.org/ IMGTrepertoireMH/ [49], accessed on 8 January 2022). We, therefore, speculate that other 
m02 family members that carry an AP-2 binding YXX $\Phi$ motif take on an m04-equivalent role for MHC-I molecules of $H$-2 haplotypes not targeted by m04.

The divergent pathways of intracellular sorting determined by the AP binding motifs already suggest that proteins $\mathrm{m} 04$ and $\mathrm{m} 06$ act antagonistically and compete for pMHC-I cargo. In fact, pMHC-I captured by $\mathrm{m} 04$ traffics to the cell surface [25], where the complex binds to the endocytic adapter AP-2 that internalizes it by mediating clathrin-assisted endocytosis [29,50-52], whereas binding by $\mathrm{m} 06$ ends up in lysosomal disposal [33-35]. Inactivating the m06 di-leucine motif by replacing LL with AA was found to block the transition of m06-MHC-I complexes from early endosomes to late endosomes, and thus prevent lysosomal degradation [36].

The period during which m04-pMHC-I complexes are displayed at the cell surface is apparently long enough to silence NK cells by binding to inhibitory Ly49 family receptors Ly49A, Ly49C, and Ly49G2 [25-30]. Inhibition of AP-2 mediated endocytosis by a motif mutation Y248A, replacing the crucial Tyr with Ala, was found to intensify NK cell silencing, in accordance with an extended cell surface half-life of m04-pMHC-I complexes [29].

So, $\mathrm{m} 04$ can be viewed as being an innate immunity NK cell immunoevasin. However, an MHC-I allele-specific exception exists: cell surface display of m04- $\mathrm{D}^{\mathrm{k}}$ activates NK cells by binding to the activatory Ly49 family receptors Ly49P1, Ly49L, and Ly49D2 [53,54]. This complexity in NK cell silencing or activation again highlights the importance of MHC-I polymorphism in virus-host co-evolution.

As already shown by $\mathrm{Lu}$ and colleagues [27], m04 can bind to empty MHC-I K ${ }^{\mathrm{b}}$ in cell lines deficient in peptide-transport from the cytosol into the ER by deletion of the TAP transporter, but the presence of a $\mathrm{K}^{\mathrm{b}}$-presented viral peptide stabilized the complex. So, m04-pMHC-I complexes travel to the cell surface and have the potential to present viral peptides to $\mathrm{CD} 8^{+} \mathrm{T}$ cells for mediating antiviral control. Although the structural analysis by Berry and colleagues [24] has not precisely mapped the m04 binding site to the MHC class-I $\alpha$-chain, the data suggest that the peptide-binding platform is not sterically masked, so that the TCR of $\mathrm{CD} 8^{+} \mathrm{T}$ cells should be able to recognize presented peptide. Nonetheless, it was previously speculated that $\mathrm{m} 04$ might act as an immunoevasin by preventing the m04-pMHC complex from being recognized by the TCR [26]. As a further potential sterical hindrance, viral protein MATp1 was found to be essential for m04-mediated MHC-I cell surface trafficking [30].

Using combinatorial deletion of the discussed mCMV immunoevasins $\mathrm{m} 04, \mathrm{~m} 06$, and $\mathrm{m} 152$ (see below) in the $\mathrm{mCMV}$ genome revealed an anti-immunoevasive role of $\mathrm{m} 04$ in recognition of infected cells by $\mathrm{CD} 8^{+} \mathrm{T}$ cells $[31,55]$, which was confirmed more recently after retrospective verification of the authenticity of the viral mutants involved [32]. This finding prompted us to suggest the acronym vRAP (viral regulator of antigen presentation) to account for both negative and positive roles of viral proteins in pMHC-I cell surface trafficking and presentation to $\mathrm{CD} 8^{+} \mathrm{T}$ cells.

\section{The $m 145$ Gene Family}

Known key features of $m 145$ gene family members are compiled in Table 2. 
Table 2. Members of the $m 145$ gene family. Experimentally determined molecular masses refer to prevalent glycosylated isoforms; (-) not studied or not applicable.

\begin{tabular}{|c|c|c|c|c|c|c|}
\hline Gene/Protein & $\begin{array}{l}\text { Molecular } \\
\text { Mass }\end{array}$ & $\begin{array}{l}\text { Protein } \\
\text { Structure }\end{array}$ & $\begin{array}{l}\text { Binding } \\
\text { Partner }\end{array}$ & $\begin{array}{l}\text { Receptor of Cell } \\
\text { Surface Ligand }\end{array}$ & $\begin{array}{l}\text { Role in } \\
\text { Immunity }\end{array}$ & Ref. \\
\hline$m 145$ & $53 \mathrm{kDa}$ & - & MULT-1 & NKG2D & NK cell evasion & [56] \\
\hline$m 146$ & - & - & - & - & - & \\
\hline$m 150$ & - & - & - & - & - & \\
\hline$m 151$ & - & - & - & - & - & \\
\hline \multirow{3}{*}{ m152/gp40 } & \multirow{3}{*}{$\begin{array}{l}48 \mathrm{kDa} / \\
40 \mathrm{kDa}\end{array}$} & \multirow{3}{*}{$\begin{array}{c}\text { PDB ID } \\
4 G 59[57]\end{array}$} & MHC-I & TCR & \multirow{3}{*}{$\begin{array}{c}\text { T cell evasion } \\
\text { NK cell } \\
\text { evasion; } \\
\text { Innate } \\
\text { immunity }\end{array}$} & {$[19,58-60]$} \\
\hline & & & RAE-1 & NKG2D & & [61-64] \\
\hline & & & STING & - & & {$[65]$} \\
\hline$m 153$ & $80 \mathrm{kDa}$ & 2O5N [66] & Clr-b & NKR-P1B & NK cell evasion & {$[67,68]$} \\
\hline$m 154$ & $60 \mathrm{kDa}$ & - & $\begin{array}{l}\text { AP-1 cargo: } \\
\text { CD18, CD47, } \\
\text { CD48, CD54, } \\
\text { CD } 84, \text { CD155, } \\
\text { CD162, CD229, } \\
\text { CD262, CD270 }\end{array}$ & $\begin{array}{c}\text { CD244 } \\
\text { (for CD48) }\end{array}$ & $\begin{array}{l}\text { Broad immune } \\
\text { evasion } \\
\text { NK cells and } \\
\text { CD8 }{ }^{+} \mathrm{T} \text { cells }\end{array}$ & {$[69,70]$} \\
\hline \multirow{2}{*}{ m155 } & \multirow{2}{*}{$60 \mathrm{kDa}$} & \multirow{2}{*}{ - } & H60 & NKG2D & \multirow{2}{*}{$\begin{array}{c}\text { NK cell evasion } \\
\mathrm{CD}^{+} \mathrm{T} \text { cell } \\
\text { evasion }\end{array}$} & {$[71,72]$} \\
\hline & & & $\mathrm{CD} 40$ & CD40L & & [73] \\
\hline$m 157$ & $42-50 \mathrm{kDa}$ & $\begin{array}{l}\text { PDB ID 2NYK } \\
\text { [74]; 4JO8 [75] }\end{array}$ & & Ly49H & $\begin{array}{l}\text { Activation of } \\
\text { NK cells }\end{array}$ & [76-82] \\
\hline$m 158$ & - & - & - & - & - & \\
\hline
\end{tabular}

Members of the m145 family usually represent MHC-I-like virally encoded (MHC-Iv) integral type-I membrane glycoproteins that interact with classical MHC-I ( $\alpha$ chain) or with cellular MHC-I-like proteins. Specifically, the crystal structure of the complex between m152/gp40 of mCMV and the cellular RAE1 $\gamma$ ligand of the activatory NK cell receptor NKG2D revealed a paradigm for MHC/MHC interaction in immune evasion [57]. Some m145 family members mediate NK cell evasion by downmodulation of NKG2D ligands. Examples are $\mathrm{m} 145, \mathrm{~m} 152$, and $\mathrm{m} 155$ that bind to and thus downmodulate MULT-1, RAE-1 family members, and H60, respectively (Table 2). Particular attention in high-ranking journals was paid to $\mathrm{m} 157$, which activates the $\mathrm{Ly} 49 \mathrm{H}^{+}$subset of $\mathrm{NK}$ cells by direct $\mathrm{m} 157-$ $\mathrm{Ly} 49 \mathrm{H}$ interaction, which results in just the opposite of viral immune evasion. However, the evolutionary advantage for the virus is unclear, and in fact, the phenomenon is limited to the C57BL/ 6 laboratory mouse strain, in which $\mathrm{Ly} 49 \mathrm{H}^{+}$cells are present. Most important to this discussion is the work by McWhorter and colleagues [82], who have shown in C57BL/ 6 mice that under conditions of within-host competition between co-infecting strains of $\mathrm{mCMV}$, those which expressed an $\mathrm{m} 157$ gene product capable of ligating Ly $49 \mathrm{H}$ were outcompeted by strains expressing variant $\mathrm{m} 157$ proteins unable to ligate $\mathrm{Ly} 49 \mathrm{H}$. Thus, in virus evolution, $\mathrm{m} 157$ is maintained in its original sequence only in wild-derived mice not expressing $\mathrm{Ly} 49 \mathrm{H}$, and its actual biological function in virus-host co-evolution is still open to question.

The mCMV m152/gp40 glycoprotein was the first immune evasion protein identified for a CMV by the group of U.H. Koszinowski $[18,19,58]$. Of particular interest is the finding that it simultaneously mediates evasion of $\mathrm{CD} 8^{+} \mathrm{T}$ cells and NK cells by downmodulating cell surface expression of classical PMHC-I and of RAE-1 family ligands of the activatory NK cell receptor NKG2D, respectively [61].

Regarding the mechanism, m152 binds to luminal domains of its interaction partners in the ER and traps the complexes in a cis-Golgi/ER-Golgi intermediate compartment (ERGIC) [83-86]. It exists in differentially glycosylated isoforms, but the unglycosylated p36 proved to be sufficient for its retention function [84]. The crystal structure of the m152- 
RAE1 $\gamma$ complex indicated direct binding of the $\alpha 1 / \alpha 2$ helices of RAE1 to the $\alpha 1 / \alpha 2$ and $\alpha 3$ domains of $\mathrm{m} 152$ [57], and also predicted direct binding of $\mathrm{m} 152$ to the $\alpha 1 / \alpha 2$ domains of the MHC-I $\alpha$ chain. Whereas earlier work proposed a transient contact [83], experimental evidence for true binding was presented more recently [85]. The linker between the luminal and the transmembrane domain of 152 proved important for MHC-I retention. Replacing the authentic 43-amino-acid linker [57] with a (GGGGS) 9 tandem sequence led to rapid degradation of m152 and loss of its MHC-I retention function [85], resulting in normal levels of pMHC-I cell surface expression. TMED10, a transmembrane protein involved in COPI- and COPII-mediated vesicular export, binds to the linker sequence of m152 and thereby anchors m152 to the ERGIC, thus retaining bound pMHC-I in the ERGIC $[85,86]$.

Recent work has shown an additional function of m152 by its targeting of STING, which plays a central role in intrinsic immunity. After activation by the DNA-sensing molecule cGAS, STING dimerizes and travels from the ER to the Golgi, where it is responsible for the activation of IRF3 and $\mathrm{NFK}_{\mathrm{B}}$, resulting in the induction of type-I IFNs and proinflammatory cytokines. Translocation of STING from the ER to the Golgi is slowed down by m152, ultimately leading to a decreased translocation of IRF3 to the nucleus and, consequently, to reduced expression of antiviral type-I IFNs [65].

\section{The Immune Evasion Enigma in Cytomegalovirus Memory Inflation}

The function of viral immune evasion molecules has been established in models of acute, productive infection. Hallmarks of CMV infections are the establishment of latent infection, referred to as "latency", in certain cell types after clearance of the productive infection (for a review, see [87]) as well as "memory inflation" (MI) that is associated with latency (for reviews, see [88,89]). MI is defined as the expansion of the pool of virus epitopespecific inflationary $\mathrm{T}$ effector-memory $\mathrm{CD}^{+} \mathrm{T}$ cells (iTEM) that are characterized by the cell surface phenotype KLRG1 ${ }^{+} \mathrm{CD}_{22} \mathrm{~L}^{-}$[90]. Maintenance of KLRG1 ${ }^{+}$expression by iTEM depends on repetitive antigen presentation during latent infection [91-94]. Antigen-driven MI during latency raised the question of why immune evasion molecules m06 and m152 fail to prevent the presentation of pMHC-I to inflationary iTEM.

The solution to this enigma was provided only recently through analysis of viral transcription patterns in latently infected lungs (Figure 3) [95]. In general thinking, it was implicitly assumed that MI is driven by virus reactivation from latency [96], even though completion of the viral replicative cycle by virion assembly and release was shown to be not essential for MI to occur [97]. According to this "reactivation hypothesis", antigenic viral peptides are derived from proteins synthesized in a cell during a reactivated viral replication cycle that is characterized by temporally coordinated gene expression progressing from immediate-early (IE) to early (E) and late (L) gene expression. Yet, if this applies, immune evasion proteins, which belong to the kinetic class of E proteins, are inevitably expressed in every cell in which antigenic proteins are processed and should thus inhibit pMHC-I cell surface presentation and iTEM restimulation. As an alternative, the "stochastic expression hypothesis" predicted a random and transient desilencing of individual genes in still latent viral genomes, so that antigen-encoding genes and immune evasion genes are rarely expressed coincidentally in the same cell. This allows antigen presentation and restimulation of iTEM by cells in which antigen-encoding genes are desilenced while immune evasion genes remain silenced (Figure 3A). Analysis of viral transcription in lung tissue pieces of latently infected HCT recipients in the mouse model (Figure 3B) indeed revealed random patterns of gene expression in support of the "stochastic expression hypothesis" (Figure 3C) [95]. In perspective, future experiments should address the question of whether stochastic expression of immunoevasins m06 or m152 in a latently infected cell activates or silences NK cells by the downmodulation of cell surface MHC-I loaded with cellular self-peptides ("missing self" activation) or of ligand RAE-1 of the activatory NK cell receptor NKG2D, respectively. 
A

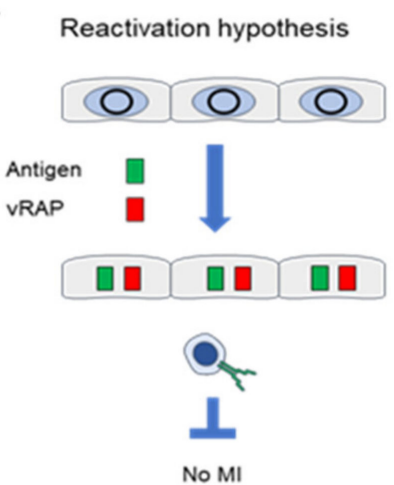

Stochastic expression hypothesis

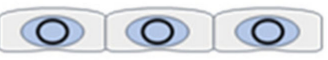

문

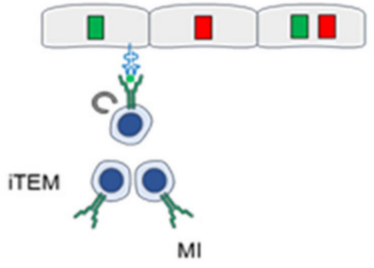

B
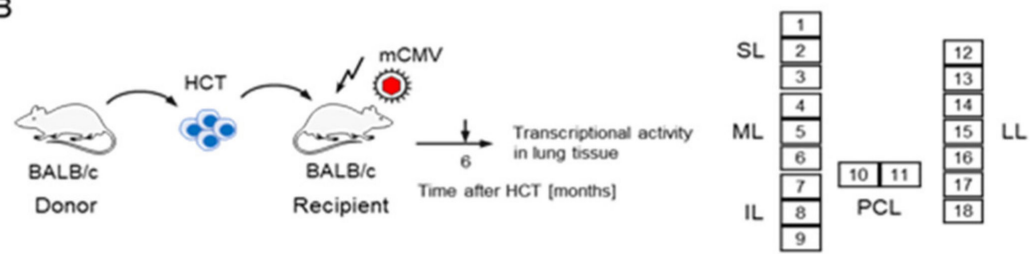

C

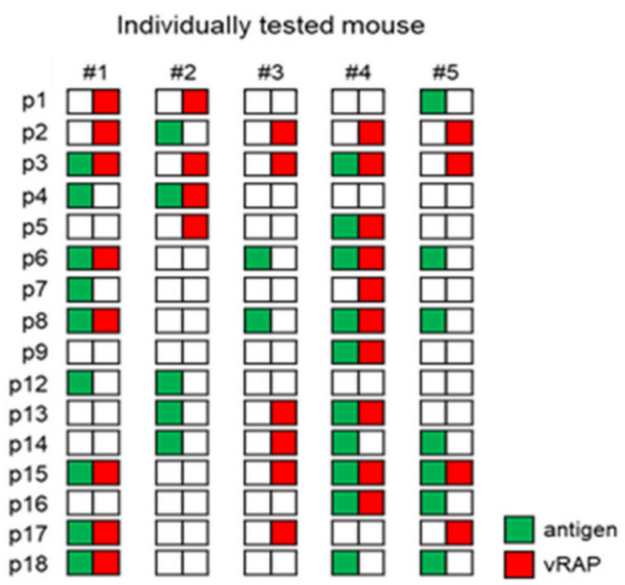

Figure 3. (A) Alternative models of viral gene expression during latency. (Circle) latent viral genome in the nucleus of a latently infected cell. (Antigen) IE1 and/or m164 peptide; (vRAP) m06 and/or m152; (MI) memory inflation; (iTEM) inflationary T effector-memory CD8 ${ }^{+} \mathrm{T}$ cell. (B) BALB/c $\left(H-2^{d}\right)$ HCT model for establishing mCMV latency in the lungs. For the analysis of transcripts by RT-PCR, lungs are cut into 18 pieces, p1-p18; (SL, ML, IL) superior, middle, and inferior lobe of the right lung; (PCL) post-caval lobe; (LL) left lung. (C) Experimentally observed random transcription patterns in 5 mice (\#1-\#5) tested individually. Reproduced from reference [95] in a new arrangement.

\section{Concerted Action of vRAPs in Acute Infection}

Unlike in latency, when stochastic gene expression can lead to isolated expression of individual immune evasion genes, presentation of antigenic peptides as pMHC-I complexes at the cell surface is regulated by a concerted action during acute infection. To unravel the interplay between the positive vRAP m04 and the negative vRAPs m06 and m152, recent work pursued the strategy of stepwise combination [32] (Figure 4). Antigen presentation was assessed in vivo in immunocompromised C57BL/6 $\left(\mathrm{H}-2^{b}\right)$ mice through control of liver infection after adoptive transfer of $\mathrm{CD}^{+}$cytolytic $\mathrm{T}$ lymphocytes (CTL) specific for the antigenic viral peptide M45- $\mathrm{D}^{\mathrm{b}}$ \{985-HGIRNASFI-993\} presented by MHC-I $\mathrm{D}^{\mathrm{b}}$ [98] (M45-D ${ }^{\mathrm{b}}$ CTL). 
A

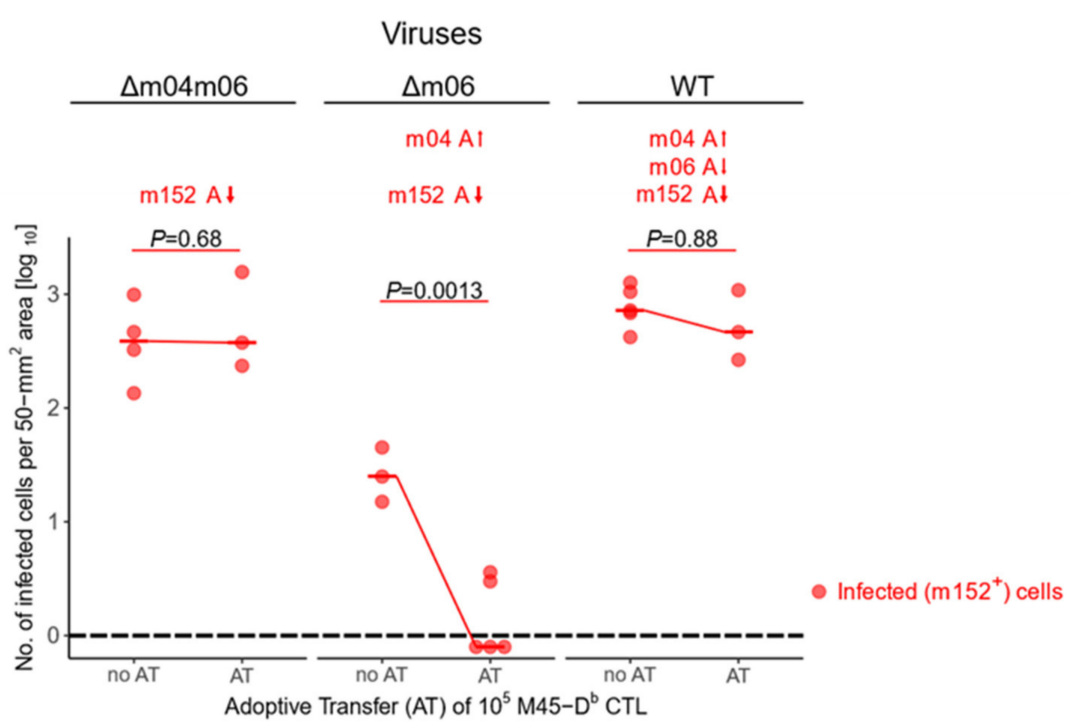

B
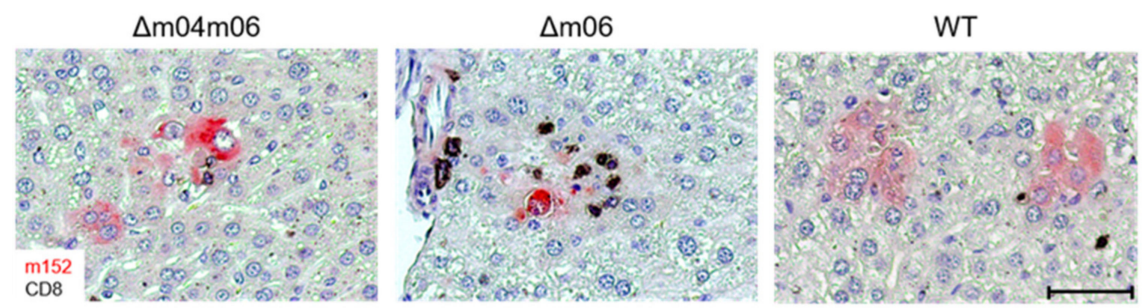

Figure 4. (A) Adoptive transfer of $M 45-D^{b}$ CTL into immunocompromised C57BL/ 6 mice infected with viruses $\mathrm{mCMV}-\Delta \mathrm{m} 04 \mathrm{~m} 06$, selectively expressing vRAP m152, $\mathrm{mCMV}-\Delta \mathrm{m} 06$ expressing vRAPs m152 and m04, as well as wild-type (WT) mCMV expressing vRAPs m152, m04, and m06. Data represent infected $\mathrm{m} 152^{+}$cells present in $50-\mathrm{mm}^{2}$ areas of liver tissue sections. The red dot symbol represents mice tested individually. Median values are marked and connected for comparison. (A-arrow up or down), positive or negative effect on antigen presentation, respectively; (AT) adoptive transfer. $P$ values for comparing groups with or without AT were calculated by a Student's $t$-test with Welch's correction for unequal variances. Differences are considered significant for $P<0.05$. The dashed line represents the detection limit of the assay. Note that the lower viral load in the "no $\mathrm{AT}^{\prime \prime}$ group of infection with $\mathrm{mCMV}-\Delta \mathrm{m} 06$ does not reflect virus attenuation but results from a lower initial dose of infection. Reproduced from [32] in a new arrangement. (B) Representative images of liver tissue sections stained by 2-color immunohistochemistry and hematoxylin counter-staining. (Red) Infected liver cells, mostly hepatocytes, identified by a cytoplasmic expression of m152 that is shared by all three viruses; (Black) Tissue-infiltrating CD8 ${ }^{+}$T cells. Bar marker: $50 \mu \mathrm{m}$. Reproduced from reference [32] in a new marker combination.

This peptide was chosen for the analysis as its presentation is utmost sensitive to regulation. It represents the prototype of a "non-protective epitope", as originally defined by the failure of M45-D ${ }^{b}$ CTL to control infection by wild-type (WT) virus expressing all three vRAPs, despite an exquisitely high functional avidity of the CTL used $[60,98,99]$. The explanation for this observation is the very low efficacy of antigen processing generating this peptide, leading to a yield of only 10 molecules per WT-virus infected cell, compared to $\sim 6000$ molecules of the protective viral peptide M45-D ${ }^{\mathrm{d}}\{507-V G P A L G R G L-515\}$ processed from the same protein and presented by MHC-I $D^{\mathrm{d}}$ [99]. Notably, the deletion of just vRAP $\mathrm{m} 152$ in virus $\mathrm{mCMV}-\Delta \mathrm{m} 152$ restored $M 45-\mathrm{D}^{\mathrm{b}}$ presentation in infected cells as well as in vivo antiviral protection by M45-D ${ }^{\mathrm{b}}$ CTL upon adoptive transfer $[60,99]$. Likewise, IFN $\gamma$ enhanced processing in WT-virus infected cells generated 1000 molecules of the M45-D ${ }^{b}$ peptide, resulting in cell surface presentation sufficient for recognition by high-avidity M45-D ${ }^{b}$ CTL. Accordingly, adoptive transfer of M45-D ${ }^{b}$ CTL protected against in vivo WT 
virus infection in transgenic B6-SAP-IFN $\gamma$ mice constitutively producing high serum levels of IFN $\gamma[100]$.

In the study of the concerted action of the three vRAPs in immunocompromised adoptive transfer recipients (Figure 4), expression of just $\mathrm{m} 152$ by mCMV- $\Delta \mathrm{m} 04 \mathrm{~m} 06$ completely prevented protection by $\mathrm{M} 45-\mathrm{D}^{\mathrm{b}} \mathrm{CTL}$, whereas the addition of $\mathrm{m} 04$ restored protection in recipients infected with $\mathrm{mCMV}-\Delta \mathrm{m} 06$. This positive regulatory function of $\mathrm{m} 04$ was almost completely antagonized by the addition of vRAP m06 in recipients infected with the WT virus (Figure 4A). Corresponding 2-color immunohistological images of liver tissue sections show a high degree of infection with only a few tissue-infiltrating CD8 ${ }^{+} \mathrm{T}$ cells, that are M45- $\mathrm{D}^{\mathrm{b}} \mathrm{CTL}$, after infection with $\mathrm{mCMV}-\Delta \mathrm{m} 04 \mathrm{~m} 06$, whereas additional expression of $\mathrm{m} 04$ by $\mathrm{mCMV}-\Delta \mathrm{m} 06$ recruits M45-D ${ }^{\mathrm{b}} \mathrm{CTL}$ to infected cells, thereby forming nodular inflammatory foci (NIF), which are known histological correlates for viral epitope-specific protective activity [101]. Finally, additional expression of vRAP m06 by WT-virus prevented protective NIF formation (Figure 4B).

\section{Synopsis of vRAP Interplay in Regulating Antigen Presentation}

It is the main function of vRAPs to direct recently peptide-loaded pMHC-I complexes from the ER into sorting pathways [102]. Accordingly, they bind to their pMHC-I cargo in the ER and determine its intracellular trafficking. When expressed in the absence of vRAPs $\mathrm{m} 04$ and $\mathrm{m} 06$ after infection with $\mathrm{mCMV}-\Delta \mathrm{m} 04 \mathrm{~m} 06$, vRAP m152 has the chance to bind to essentially all recently-loaded pMHC-I complexes and traps them in the ERGIC, so that cell surface presentation is largely prevented (Figure 5, left). When vRAP m04 comes additionally in case of infection with mCMV- $\Delta \mathrm{m} 06$, it successfully competes with $\mathrm{m} 152$ for pMHC-I molecules, presumably by binding with higher affinity, and rescues them from getting trapped in the ERGIC, which results in cell surface presentation of m04-pMHC-I complexes. This rescue is incomplete, as m04 is expressed later than m152 in the viral gene expression program. By binding to cellular adapter protein AP-2 through the endocytic YXXФ motif in the cytosolic tail of m04, m04-pMHC-I complexes are removed from the cell surface by clathrin-assisted endocytosis, which reduces their cell surface presentation half-life (Figure 5, center). Finally, when m06 comes in addition in the case of infection with WT virus, it competes with m04 for pMHC-I binding and directs part of them into the endosomal-lysosomal pathway for degradation by linking the complexes to cellular adapter proteins AP-1A and AP-3A through the di-leucine motif in its cytosolic tail (Figure 5, right).

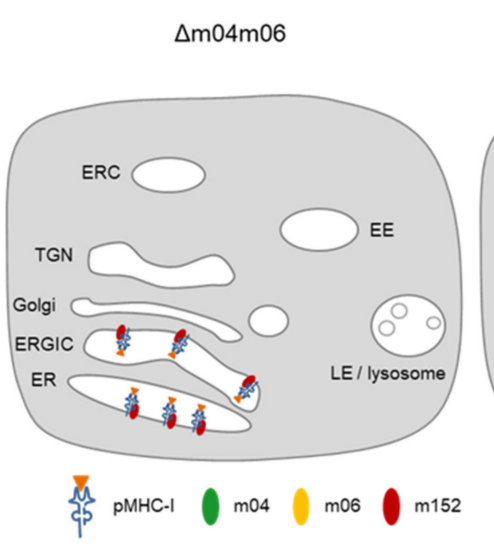

\section{Viruses}

$\Delta \mathrm{m} 06$
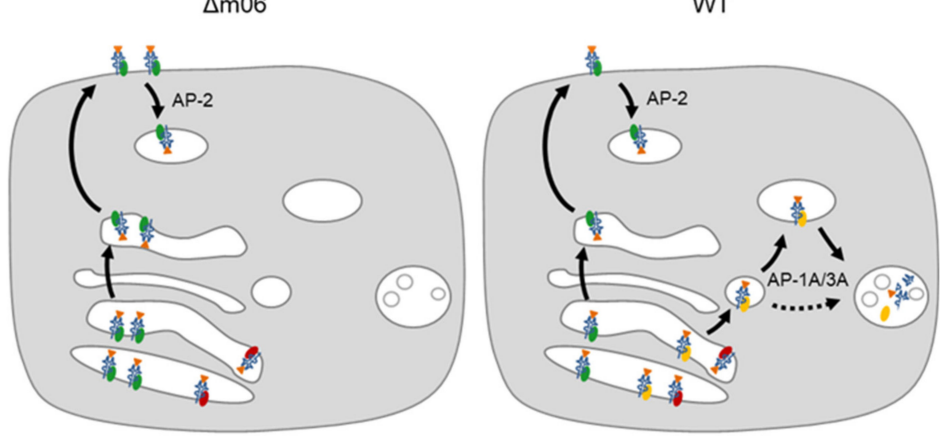

Figure 5. Graphical abstracts explaining agonistic and antagonistic vRAP functions. (ER), endoplasmic reticulum; (ERGIC), ER Golgi-intermediate compartment; (TGN), trans-Golgi network; (ERC), endosomal recycling compartment. Note that an early gene function of $\mathrm{mCMV}$ blocks cargo recycling from the ERC to the cell surface [103]; (EE), early endosome; (LE), Late endosome; AP, cellular adapter protein. Solid arrows indicate main pathways; the dashed arrow indicates an alternative route. 
Immune evasion conveys an evolutionary advantage to virus variants upon host co-infection with multiple variants competing for virus spread in host organs and host-tohost transmission. The finding that m152 is sufficient for preventing the presentation of antigenic peptides to $\mathrm{CD}^{+} \mathrm{T}$ cells raises the question of why successful virus variants have additionally acquired the complicated antagonism between $\mathrm{m} 04$ and m06. One idea for discussion is that m04 was acquired to counter-act "missing self" activation of NK cells by restoring "self" for NK cell silencing. This function in NK evasion, however, comes at the expense of evading CD8 ${ }^{+} \mathrm{T}$ cells. To avoid this, m06 was acquired to limit cell surface expression of m04-pMHC-I complexes, thereby balancing and optimizing both NK cell and $\mathrm{CD}^{+} \mathrm{T}$ cell evasion.

While the acquisition of vRAPs is to the advantage of the virus and has thus driven viral evolution, immune evasion can result in severe medical problems. As we have shown recently, vRAP-mediated reduction in viral antigen presentation is responsible for lethal viral pathogenesis from unrestricted virus spread in mouse models of major or minor histocompatibility antigen mismatched HCT ([104,105], reviewed in [106]).

\section{Conclusions and Outlook}

More and more, the picture emerges that the interplay between the different viral immune evasion proteins has evolved to balance innate immunity by NK cells and adaptive immunity by T cells. Currently, however, our view is narrowed by low MHC polymorphism coverage of mouse models preferentially used in experimental studies. In Tables 1 and 2, we have compiled what is known about the members of the $m 02$ and $m 145$ gene families, respectively, mostly based on studies of MHC haplotypes $\mathrm{H}-2^{b}, \mathrm{H}-2^{d}$, and $\mathrm{H}-2^{k}$. The gaps in the lists are not of less importance, however. The as yet unidentified roles of many of the gene family members may further refine the picture and complete it in terms of viral adaptation to MHC polymorphism.

Author Contributions: Writing-original draft preparation, M.J.R.; writing-review and editing, S.B., A.F., and N.A.L.; display items, S.B., J.P., and N.A.L.; literature compilation, S.B. All authors contributed to manuscript revision and approved the submitted version. All authors have read and agreed to the published version of the manuscript.

Funding: Research from the authors was funded by the Deutsche Forschungsgemeinschaft, Collaborative Research Center (CRC) 1292: individual project TP11 ‘Viral evasion of innate and adaptive immune cells and inbetweeners'.

Institutional Review Board Statement: Not applicable.

Informed Consent Statement: Not applicable.

Data Availability Statement: The data presented in this study are available on request from the corresponding author.

Conflicts of Interest: The authors declare no conflict of interest.

\section{References}

1. Davison, A.J.; Holton, M.; Dolan, A.; Dargan, D.J.; Gatherer, D.; Hayward, G.S. Comparative genomics of primate cytomegaloviruses. In Cytomegaloviruses: From Molecular Pathogenesis to Intervention; Reddehase, M.J., Ed.; Caister Academic Press: Norfolk, UK, 2013; Volume 1, pp. 1-22.

2. Ho, M. The history of cytomegalovirus and its diseases. Med. Microbiol. Immunol. 2008, 197, 65-73. [CrossRef] [PubMed]

3. Boppana, S.B.; Britt, W.J. Synopsis of clinical aspects of human cytomegalovirus disease. In Cytomegaloviruses: From Molecular Pathogenesis to Intervention; Reddehase, M.J., Ed.; Caister Academic Press: Norfolk, UK, 2013; Volume 2, pp. 1-25.

4. Cannon, M.J.; Grosse, S.D.; Fowler, K.B. The epidemiology and public health impact of congenital cytomegalovirus infection. In Cytomegaloviruses: From Molecular Pathogenesis to Intervention; Reddehase, M.J., Ed.; Caister Academic Press: Norfolk, UK, 2013; Volume 2, pp. 26-48.

5. Adler, S.P.; Nigro, G. Clinical cytomegalovirus research: Congenital infection. In Cytomegaloviruses: From Molecular Pathogenesis to Intervention; Reddehase, M.J., Ed.; Caister Academic Press: Norfolk, UK, 2013; Volume 2, pp. 55-73.

6. Avery, R.K. Clinical cytomegalovirus research: Thoracic organ transplantation. In Cytomegaloviruses: From Molecular Pathogenesis to Intervention; Reddehase, M.J., Ed.; Caister Academic Press: Norfolk, UK, 2013; Volume 2, pp. 286-300. 
7. Emery, V.C.; Milne, R.S.B.; Griffiths, P.D. Clinical cytomegalovirus research: Liver and kidney transplantation. In Cytomegaloviruses: From Molecular Pathogenesis to Intervention; Reddehase, M.J., Ed.; Caister Academic Press: Norfolk, UK, 2013; Volume 2, pp. 301-311.

8. Seo, S.; Boeckh, M. Clinical cytomegalovirus research: Hematopoietic cell transplantation. In Cytomegaloviruses: From Molecular Pathogenesis to Intervention; Reddehase, M.J., Ed.; Caister Academic Press: Norfolk, UK, 2013; Volume 2, pp. $337-353$.

9. Stern, L.; Withers, B.; Avdic, S.; Gottlieb, D.; Abendroth, A.; Blyth, E.; Slobedman, B. Human cytomegalovirus latency and reactivation in allogeneic hematopoietic stem cell transplant recipients. Front. Microbiol. 2019, 10, 1186. [CrossRef] [PubMed]

10. Griffiths, P.; Reeves, M. Pathogenesis of human cytomegalovirus in the immunocompromised host. Nat. Rev. Microbiol. 2021, 19, 759-773. [CrossRef] [PubMed]

11. Reddehase, M.J. Antigens and immunoevasins: Opponents in cytomegalovirus immune surveillance. Nat. Rev. Immunol. 2002, 2, 831-844. [CrossRef]

12. Powers, C.; DeFilippis, V.; Malouli, D.; Früh, K. Cytomegalovirus immune evasion. Curr. Top. Microbiol. Immunol. 2008, 325, 333-359. [PubMed]

13. Lisnić, B.; Lisnić, V.J.; Jonjić, S. NK cell interplay with cytomegaloviruses. Curr. Opin. Virol. 2015, 15, 9-18. [CrossRef]

14. Stempel, M.; Chan, B.; Brinkmann, M.M. Coevolution pays off: Herpesviruses have the license to escape the DNA sensing pathway. Med. Microbiol. Immunol. 2019, 208, 495-512. [CrossRef]

15. Berry, R.; Watson, G.M.; Jonjic, S.; Degli-Esposti, M.A.; Rossjohn, J. Modulation of innate and adaptive immunity by cytomegaloviruses. Nat. Rev. Immunol. 2019, 20, 113-127. [CrossRef] [PubMed]

16. Fielding, C.A.; Weekes, M.P.; Nobre, L.V.; Ruckova, E.; Wilkie, G.S.; Paulo, J.A.; Chang, C.; Suárez, N.M.; Davies, J.A.; Antrobus, R.; et al. Control of immune ligands by members of a cytomegalovirus gene expansion suppresses natural killer cell activation. Elife 2017, 6, e22206. [CrossRef] [PubMed]

17. Reddehase, M.J.; Lemmermann, N.A. Mouse model of cytomegalovirus disease and immunotherapy in the immunocompromised host: Predictions for medical translation that survived the "test of time". Viruses 2018, 10, 693. [CrossRef] [PubMed]

18. Del Val, M.; Münch, K.; Reddehase, M.J.; Koszinowski, U.H. Presentation of CMV immediate-early antigen to cytolytic T lymphocytes is selectively prevented by viral genes expressed in the early phase. Cell 1989, 58, 305-315. [CrossRef]

19. Del Val, M.; Hengel, H.; Häcker, H.; Hartlaub, U.; Ruppert, T.; Lucin, P.; Koszinowski, U.H. Cytomegalovirus prevents antigen presentation by blocking the transport of peptide-loaded major histocompatibility complex class I molecules into the medial-Golgi compartment. J. Exp. Med. 1992, 176, 729-738. [CrossRef]

20. Rawlinson, W.D.; Farrell, H.E.; Barrell, B.G. Analysis of the complete DNA sequence of murine cytomegalovirus. J. Virol. 1996, 70, 8833-8849. [CrossRef] [PubMed]

21. Redwood, A.J.; Shellam, G.R.; Smith, L.M. Molecular evolution of murine cytomegalovirus genomes. In Cytomegaloviruses: From Molecular Pathogenesis to Intervention; Reddehase, M.J., Ed.; Caister Academic Press: Norfolk, UK, 2013; Volume 1, pp. $23-37$.

22. Oliveira, S.A.; Park, S.H.; Lee, P.; Bendelac, A.; Shenk, T.E. Murine cytomegalovirus m02 gene family protects against natural killer cell-mediated immune surveillance. J. Virol. 2002, 76, 885-894. [CrossRef]

23. Corbett, A.J.; Forbes, C.A.; Moro, D.; Scalzo, A.A. Extensive sequence variation exists among isolates of murine cytomegalovirus within members of the $\mathrm{m} 02$ family of genes. J. Gen. Virol. 2007, 88, 758-769. [CrossRef]

24. Berry, R.; Vivian, J.P.; Deuss, F.A.; Balaji, G.R.; Saunders, P.M.; Lin, J.; Littler, D.R.; Brooks, A.G.; Rossjohn, J. The structure of the cytomegalovirus-encoded $\mathrm{m} 04$ glycoprotein, a prototypical member of the m02 family of immunoevasins. J. Biol. Chem. 2014, 289, 23753-23763. [CrossRef]

25. Kleijnen, M.F.; Huppa, J.B.; Lucin, P.; Mukherjee, S.; Farrell, H.; Campbell, A.E.; Koszinowski, U.H.; Hill, A.B.; Ploegh, H.L. A mouse cytomegalovirus glycoprotein, gp34, forms a complex with folded class I MHC molecules in the ER which is not retained but is transported to the cell surface. EMBO J. 1997, 16, 685-694. [CrossRef] [PubMed]

26. Kavanagh, D.G.; Koszinowski, U.H.; Hill, A.B. The murine cytomegalovirus immune evasion protein $\mathrm{m} 4 / \mathrm{gp} 34$ forms biochemically distinct complexes with class I MHC at the cell surface and in a pre-Golgi compartment. J. Immunol. 2001, 167, 3894-3902. [CrossRef]

27. Lu, X.; Kavanagh, D.G.; Hill, A.B. Cellular and molecular requirements for association of the murine cytomegalovirus protein m4/gp34 with major histocompatibility complex class I molecules. J. Virol. 2006, 80, 6048-6055. [CrossRef]

28. Babić, M.; Pyzik, M.; Zafirova, B.; Mitrović, M.; Butorac, V.; Lanier, L.L.; Krmpotić, A.; Vidal, S.M.; Jonjić, S. Cytomegalovirus immunoevasin reveals the physiological role of "missing self" recognition in natural killer cell dependent virus control in vivo. J. Exp. Med. 2010, 207, 2663-2673. [CrossRef] [PubMed]

29. Fink, A.; Blaum, F.; Babic Cac, M.; Ebert, S.; Lemmermann, N.A.; Reddehase, M.J. An endocytic YXX $\Phi$ (YRRF) cargo sorting motif in the cytoplasmic tail of murine cytomegalovirus AP2 'adapter adapter' protein m04/gp34 antagonizes virus evasion of natural killer cells. Med. Microbiol. Immunol. 2015, 204, 383-394. [CrossRef]

30. Železnjak, J.; Lisnić, V.J.; Popović, B.; Lisnić, B.; Babić, M.; Halenius, A.; L’Hernault, A.; Roviš, T.L.; Hengel, H.; Erhard, F.; et al. The complex of MCMV proteins and MHC class I evades NK cell control and drives the evolution of virus-specific activating Ly49 receptors. J. Exp. Med. 2019, 216, 1809-1827. [CrossRef]

31. Holtappels, R.; Gillert-Marien, D.; Thomas, D.; Podlech, J.; Deegen, P.; Herter, S.; Oehrlein-Karpi, S.A.; Strand, D.; Wagner, M.; Reddehase, M.J. Cytomegalovirus encodes a positive regulator of antigen presentation. J. Virol. 2006, 80, 7613-7624. [CrossRef] 
32. Becker, S.; Fink, A.; Podlech, J.; Giese, I.; Schmiedeke, J.K.; Bukur, T.; Reddehase, M.J.; Lemmermann, N.A. Positive role of the MHC class-I antigen presentation regulator m04/gp34 of murine cytomegalovirus in antiviral protection by CD8 T cells. Front. Cell. Infect. Microbiol. 2020, 10, 454. [CrossRef] [PubMed]

33. Reusch, U.; Muranyi, W.; Lucin, P.; Burgert, H.G.; Hengel, H.; Koszinowski, U.H. A cytomegalovirus glycoprotein re-routes MHC class I complexes to lysosomes for degradation. EMBO J. 1999, 18, 1081-1091. [CrossRef]

34. Bubeck, A.; Reusch, U.; Wagner, M.; Ruppert, T.; Muranyi, W.; Kloetzel, P.M.; Koszinowski, U.H. The glycoprotein gp48 of murine cytomegalovirus: Proteasome-dependent cytosolic dislocation and degradation. J. Biol. Chem. 2002, 277, 2216-2224. [CrossRef]

35. Reusch, U.; Bernhard, O.; Koszinowski, U.; Schu, P. AP-1A and AP-3A lysosomal sorting functions. Traffic 2002, 3, 752-761. [CrossRef]

36. Fink, A.; Mikuličić, S.; Blaum, F.; Reddehase, M.J.; Florin, L.; Lemmermann, N.A. Function of the cargo sorting dileucine motif in a cytomegalovirus immune evasion protein. Med. Microbiol. Immunol. 2019, 208, 531-542. [CrossRef] [PubMed]

37. Aguilar, O.A.; Berry, R.; Rahim, M.M.A.; Reichel, J.J.; Popović, B.; Tanaka, M.; Fu, Z.; Balaji, G.R.; Lau, T.N.H.; Tu, M.M.; et al A viral immunoevasin controls innate immunity by targeting the prototypical natural killer cell receptor family. Cell 2017, 169, 58-71. [CrossRef] [PubMed]

38. Chan, B.; Arapovi, M.; Masters, L.L.; Rwandamuiye, F.; Jonjic, S.; Smith, L.M.; Redwood, A.J. The m15 locus of murine cytomegalovirus modulates natural killer cell responses to promote dissemination to the salivary glands and viral shedding. Pathogens 2021, 10, 866. [CrossRef]

39. Bonifacino, J.S.; Traub, L.M. Signals for sorting of transmembrane proteins to endosomes and lysosomes. Annu. Rev. Biochem. 2003, 72, 395-447. [CrossRef]

40. Nakatsu, F.; Ohno, H. Adaptor protein complexes as the key regulators of protein sorting in the post-Golgi network. Cell. Struct. Funct. 2003, 28, 419-429. [CrossRef]

41. Park, S.Y.; Guo, X. Adaptor protein complexes and intracellular transport. Biosci. Rep. 2014, 34, e00123. [CrossRef]

42. Redwood, A.J.; Messerle, M.; Harvey, N.L.; Hardy, C.M.; Koszinowski, U.H.; Lawson, M.A.; Shellam, G.R. Use of a murine cytomegalovirus K181-derived bacterial artificial chromosome as a vaccine vector for immunocontraception. J. Virol. 2005, 79, 2998-3008. [CrossRef]

43. Smith, L.M.; McWhorter, A.R.; Masters, L.L.; Shellam, G.R.; Redwood, A.J. Laboratory strains of murine cytomegalovirus are genetically similar to but phenotypically distinct from wild strains of virus. J. Virol. 2008, 82, 6689-6696. [CrossRef] [PubMed]

44. Smith, L.M.; McWhorter, A.R.; Shellam, G.R.; Redwood, A.J. The genome of murine cytomegalovirus is shaped by purifying selection and extensive recombination. Virology 2013, 435, 258-268. [CrossRef] [PubMed]

45. Čížková, D.; Baird, S.J.E.; Těšíková, J.; Voigt, S.; L'udovít, Ď.; Piálek, J.; Goüy de Bellocq, J. Host subspecific viral strains in European house mice: Murine cytomegalovirus in the Eastern (Mus musculus musculus) and Western house mouse (Mus musculus domesticus). Virology 2018, 521, 92-98. [CrossRef] [PubMed]

46. Cheng, T.P.; Valentine, M.C.; Gao, J.; Pingel, J.T.; Yokoyama, W.M. Stability of murine cytomegalovirus genome after in vitro and in vivo passage. J. Virol. 2010, 84, 2623-2628. [CrossRef]

47. Sgourakis, N.G.; Natarajan, K.; Ying, J.; Vogeli, B.; Boyd, L.F.; Margulies, D.H.; Bax, A. The structure of mouse cytomegalovirus m04 protein obtained from sparse NMR data reveals a conserved fold of the m02-m06 viral immune modulator family. Structure 2014, 22, 1263-1273. [CrossRef]

48. Sgourakis, N.G.; May, N.A.; Boyd, L.F.; Ying, J.; Bax, A.; Margulies, D.H. A novel MHC-I surface targeted for binding by the MCMV m06 immunoevasin revealed by solution NMR. J. Biol. Chem. 2015, 290, 28857-28868. [CrossRef]

49. Lefranc, M.P. IMGT, the international ImMunoGeneTics database. Nucleic. Acids. Res. 2003, 31, 307-310. [CrossRef]

50. Ohno, H.; Stewart, J.; Fournier, M.C.; Bosshart, H.; Rhee, I.; Miyatake, S.; Saito, T.; Gallusser, A.; Kirchhausen, T.; Bonifacino, J.S. Interaction of tyrosine-based sorting signals with clathrin-associated proteins. Science 1995, 269, 1872-1875. [CrossRef]

51. Traub, L.M. Sorting it out: AP-2 and alternate clathrin adaptors in endocytic cargo selection. J. Cell. Biol. 2003, 163, 203-208. [CrossRef]

52. Reider, A.; Wendland, B. Endocytic adaptors-social networking at the plasma membrane. J. Cell. Sci. 2011, 124, 1613-1622. [CrossRef] [PubMed]

53. Kielczewska, A.; Pyzik, M.; Sun, T.; Krmpotic, A.; Lodoen, M.B.; Munks, M.W.; Babic, M.; Hill, A.B.; Koszinowski, U.H.; Jonjic, S.; et al. Ly49P recognition of cytomegalovirus-infected cells expressing H2-D k and CMV-encoded m04 correlates with the NK cell antiviral response. J. Exp. Med. 2009, 206, 515-523. [CrossRef] [PubMed]

54. Pyzik, M.; Charbonneau, B.; Gendron-Pontbriand, E.M.; Babić, M.; Krmpotić, A.; Jonjić, S.; Vidal, S.M. Distinct MHC class I-dependent NK cell-activating receptors control cytomegalovirus infection in different mouse strains. J. Exp. Med. 2011, 208, 1105-1117. [CrossRef] [PubMed]

55. Wagner, M.; Gutermann, A.; Podlech, J.; Reddehase, M.J.; Koszinowski, U.H. Major histocompatibility complex class I allelespecific cooperative and competitive interactions between immune evasion proteins of cytomegalovirus. J. Exp. Med. 2002, 196, 805-816. [CrossRef] [PubMed]

56. Krmpotic, A.; Hasan, M.; Loewendorf, A.; Saulig, T.; Halenius, A.; Lenac, T.; Polic, B.; Bubic, I.; Kriegeskorte, A.; Pernjak-Pugel, E.; et al. NK cell activation through the NKG2D ligand MULT-1 is selectively prevented by the glycoprotein encoded by mouse cytomegalovirus gene m145. J. Exp. Med. 2005, 201, 211-220. [CrossRef] 
57. Wang, R.; Natarajan, K.; Revilleza, M.J.R.; Boyd, L.F.; Zhi, L.; Zhao, H.; Robinson, H.; Margulies, D.H. Structural basis of mouse cytomegalovirus m152/gp40 interaction with RAE1 reveals a paradigm for MHC/MHC interaction in immune evasion. Proc. Natl. Acad. Sci. USA 2012, 109, 3578-3587. [CrossRef]

58. Ziegler, H.; Thale, R.; Lucin, P.; Muranyi, W.; Flohr, T.; Hengel, H.; Farrell, H.; Rawlinson, W.; Koszinowski, U.H. A mouse cytomegalovirus glycoprotein retains MHC class I complexes in the ERGIC/cis-Golgi compartments. Immunity 1997, 6, 57-66. [CrossRef]

59. Krmpotic, A.; Messerle, M.; Crnkovic-Mertens, I.; Polic, B.; Jonjic, S.; Koszinowski, U.H. The immunoevasive function encoded by the mouse cytomegalovirus gene m152 protects the virus against T cell control in vivo. J. Exp. Med. 1999, 190, 1285-1296. [CrossRef] [PubMed]

60. Holtappels, R.; Podlech, J.; Pahl-Seibert, M.F.; Jülch, M.; Thomas, D.; Simon, C.O.; Wagner, M.; Reddehase, M.J. Cytomegalovirus misleads its host by priming of CD8 T cells specific for an epitope not presented in infected tissues. J. Exp. Med. 2004, 199, 131-136. [CrossRef] [PubMed]

61. Krmpotić, A.; Busch, D.H.; Bubić, I.; Gebhardt, F.; Hengel, H.; Hasan, M.; Scalzo, A.A.; Koszinowski, U.H.; Jonjić, S. MCMV glycoprotein gp40 confers virus resistance to CD8+ T cells and NK cells in vivo. Nat. Immunol. 2002, 3, 529-535. [CrossRef] [PubMed]

62. Lodoen, M.; Ogasawara, K.; Hamerman, J.A.; Arase, H.; Houchins, J.P.; Mocarski, E.S.; Lanier, L.L. NKG2D-mediated natural killer cell protection against cytomegalovirus is impaired by viral gp40 modulation of retinoic acid early inducible 1 gene molecules. J. Exp. Med. 2003, 197, 1245-1253. [CrossRef]

63. Zhi, L.; Mans, J.; Paskow, M.J.; Brown, P.H.; Schuck, P.; Jonjić, S.; Natarajan, K.; Margulies, D.H. Direct interaction of the mouse cytomegalovirus m152/gp40 immunoevasin with RAE-1 isoforms. Biochemistry 2010, 49, 2443-2453. [CrossRef]

64. Lis, N.; Hein, Z.; Ghanwat, S.S.; Ramnarayan, V.R.; Chambers, B.J.; Springer, S. The murine cytomegalovirus immunoevasin gp40/m152 inhibits NKG2D receptor RAE- $1 \gamma$ by intracellular retention and cell surface masking. J. Cell. Sci. 2021, 134, jcs257428. [CrossRef]

65. Stempel, M.; Chan, B.; Juranić Lisnić, V.; Krmpotić, A.; Hartung, J.; Paludan, S.R.; Füllbrunn, N.; Lemmermann, N.A.; Brinkmann, M.M. The herpesviral antagonist m152 reveals differential activation of STING -dependent IRF and NF- $\mathrm{B}$ signaling and STING 's dual role during MCMV infection. EMBO J. 2019, 38, 1-22. [CrossRef]

66. Mans, J.; Natarajan, K.; Balbo, A.; Schuck, P.; Eike, D.; Hess, S.; Robinson, H.; Šimić, H.; Jonjić, S.; Tiemessen, C.T.; et al. Cellular expression and crystal structure of the murine cytomegalovirus major histocompatibility complex class I-like glycoprotein, m153. J. Biol. Chem. 2007, 282, 35247-35258. [CrossRef]

67. Aguilar, O.A.; Mesci, A.; Ma, J.; Chen, P.; Kirkham, C.L.; Hundrieser, J.; Voigt, S.; Allan, D.S.; Carlyle, J.R. Modulation of Clr ligand expression and NKR-P1 receptor function during murine cytomegalovirus infection. J. Innate Immun. 2015, 7, 584-600. [CrossRef] [PubMed]

68. Aguilar, O.A.; Sampaio, I.S.; Rahim, M.M.A.; Samaniego, J.D.; Tilahun, M.E.; Krishnamoorthy, M.; Popović, B.; Babić, M.; Krmpotić, A.; Treanor, B.; et al. Mouse cytomegalovirus m153 protein stabilizes expression of the inhibitory NKR-P1B ligand Clr-b. J. Virol. 2019, 94, e01220-19. [CrossRef]

69. Zarama, A.; Pérez-Carmona, N.; Farré, D.; Tomic, A.; Borst, E.M.; Messerle, M.; Jonjic, S.; Engel, P.; Angulo, A. Cytomegalovirus m154 hinders CD48 cell-surface expression and promotes viral escape from host natural killer cell control. PLoS Pathog. 2014, 10, e1004000. [CrossRef] [PubMed]

70. Geljic, I.S.; Brlic, P.K.; Angulo, G.; Brizic, I.; Lisnic, B.; Jenus, T.; Lisnic, V.J.; Pietri, G.P.; Engel, P.; Kaynan, N.; et al. Cytomegalovirus protein $\mathrm{m} 154$ perturbs the adaptor protein-1 compartment mediating broad-spectrum immune evasion. Elife 2020, 9, 1-23.

71. Lodoen, M.B.; Abenes, G.; Umamoto, S.; Houchins, J.P.; Liu, F.; Lanier, L.L. The cytomegalovirus m155 gene product subverts natural killer cell antiviral protection by disruption of H60-NKG2D interactions. J. Exp. Med. 2004, 200, 1075-1081. [CrossRef]

72. Hasan, M.; Krmpotic, A.; Ruzsics, Z.; Bubic, I.; Lenac, T.; Halenius, A.; Loewendorf, A.; Messerle, M.; Hengel, H.; Jonjic, S.; et al. Selective down-regulation of the NKG2D ligand H60 by mouse cytomegalovirus m155 glycoprotein. J. Virol. 2005, 79, 2920-2930. [CrossRef] [PubMed]

73. Loewendorf, A.I.; Steinbrueck, L.; Peter, C.; Busche, A.; Benedict, C.A.; Kay-Jackson, P.C. The mouse cytomegalovirus glycoprotein m155 inhibits CD40 expression and restricts CD4 T cell responses. J. Virol. 2011, 85, 5208-5212. [CrossRef] [PubMed]

74. Adams, E.J.; Juo, Z.S.; Venook, R.T.; Boulanger, M.J.; Arase, H.; Lanier, L.L.; Garcia, K.C. Structural elucidation of the m157 mouse cytomegalovirus ligand for Ly 49 natural killer cell receptors. Proc. Natl. Acad. Sci. USA 2007, 104, 10128-10133. [CrossRef]

75. Berry, R.; Ng, N.; Saunders, P.M.; Vivian, J.P.; Lin, J.; Deuss, F.A.; Corbett, A.J.; Forbes, C.A.; Widjaja, J.M.; Sullivan, L.C.; et al. Targeting of a natural killer cell receptor family by a viral immunoevasin. Nat. Immunol. 2013, 14, 699-705. [CrossRef]

76. Brown, M.G.; Dokun, A.O.; Heusel, J.W.; Smith, H.R.; Beckman, D.L.; Blattenberger, E.A.; Dubbelde, C.E.; Stone, L.R.; Scalzo, A.A.; Yokoyama, W.M. Vital involvement of a natural killer cell activation receptor in resistance to viral infection. Science 2001, 292, 934-937. [CrossRef]

77. Arase, H.; Mocarski, E.S.; Campbell, A.E.; Hill, A.B.; Lanier, L.L. Direct recognition of cytomegalovirus by activating and inhibitory NK cell receptors. Science 2002, 296, 1323-1326. [CrossRef]

78. Smith, H.R.C.; Heusel, J.W.; Mehta, I.K.; Kim, S.; Dorner, B.G.; Naidenko, O.V.; lizuka, K.; Furukawa, H.; Beckman, D.L.; Pingel, J.T.; et al. Recognition of a virus-encoded ligand by a natural killer cell activation receptor. Proc. Natl. Acad. Sci. USA 2002, 99, 8826-8831. [CrossRef] 
79. Voigt, V.; Forbes, C.A.; Tonkin, J.N.; Degli-Esposti, M.A.; Smith, H.R.C.; Yokoyama, W.M.; Scalzo, A.A. Murine cytomegalovirus m157 mutation and variation leads to immune evasion of natural killer cells. Proc. Natl. Acad. Sci. USA 2003, 100, 13483-13488. [CrossRef]

80. Bubić, I.; Wagner, M.; Krmpotić, A.; Saulig, T.; Kim, S.; Yokoyama, W.M.; Jonjić, S.; Koszinowski, U.H. Gain of virulence caused by loss of a gene in murine cytomegalovirus. J. Virol. 2004, 78, 7536-7544. [CrossRef] [PubMed]

81. Davis, A.H.; Guseva, N.V.; Ball, B.L.; Heusel, J.W. Characterization of murine cytomegalovirus $\mathrm{m} 157$ from infected cells and identification of critical residues mediating recognition by the NK cell receptor Ly49H. J. Immunol. 2008, 181, 265-275. [CrossRef]

82. McWhorter, A.R.; Smith, L.M.; Masters, L.L.; Chan, B.; Shellam, G.R.; Redwood, A.J. Natural killer cell dependent within-host competition arises during multiple MCMV infection: Consequences for viral transmission and evolution. PLoS Pathog. 2013, 9, e1003111. [CrossRef] [PubMed]

83. Ziegler, H.; Muranyi, W.; Burgert, H.G.; Kremmer, E.; Koszinowski, U.H. The luminal part of the murine cytomegalovirus glycoprotein gp40 catalyzes the retention of MHC class I molecules. EMBO J. 2000, 19, 870-881. [CrossRef]

84. Fink, A.; Renzaho, A.; Reddehase, M.J.; Lemmermann, N.A. The p36 isoform of murine cytomegalovirus m152 protein suffices for mediating innate and adaptive immune evasion. Viruses 2013, 5, 3171-3191. [CrossRef] [PubMed]

85. Janßen, L.; Ramnarayan, V.R.; Aboelmagd, M.; Iliopoulou, M.; Hein, Z.; Majoul, I.; Fritzsche, S.; Halenius, A.; Springer, S. The murine cytomegalovirus immunoevasin gp40 binds MHC class I molecules to retain them in the early secretory pathway. J. Cell Sci. 2016, 129, 219-227. [CrossRef]

86. Ramnarayan, V.R.; Hein, Z.; Janßen, L.; Lis, N.; Ghanwat, S.; Springer, S. Cytomegalovirus gp40/m152 Uses TMED10 as ER Anchor to Retain MHC Class I. Cell Rep. 2018, 23, 3068-3077. [CrossRef]

87. Reddehase, M.J.; Lemmermann, N.A. Cellular reservoirs of latent cytomegaloviruses. Med. Microbiol. Immunol. 2019, 208, 391-403. [CrossRef] [PubMed]

88. Seckert, C.K.; Griessl, M.; Büttner, J.K.; Scheller, S.; Simon, C.O.; Kropp, K.A.; Renzaho, A.; Kühnapfel, B.; Grzimek, N.K.A.; Reddehase, M.J. Viral latency drives 'memory inflation': A unifying hypothesis linking two hallmarks of cytomegalovirus infection. Med. Microbiol. Immunol. 2012, 201, 551-566. [CrossRef]

89. Klenerman, P.; Oxenius, A. T cell responses to cytomegalovirus. Nat. Rev. Immunol. 2016, 16, 367-377. [CrossRef] [PubMed]

90. Snyder, C.M.; Cho, K.S.; Bonnett, E.L.; Van Dommelen, S.; Shellam, G.R.; Hill, A.B. Memory inflation during chronic viral infection is maintained by continuous production of short-lived, functional T cells. Immunity 2008, 29, 650-659. [CrossRef]

91. Thimme, R.; Appay, V.; Koschella, M.; Panther, E.; Roth, E.; Hislop, A.D.; Rickinson, A.B.; Rowland-Jones, S.L.; Blum, H.E.; Pircher, H. Increased expression of the NK cell receptor KLRG1 by virus-specific CD8 T cells during persistent antigen stimulation. J. Virol. 2005, 79, 12112-12116. [CrossRef] [PubMed]

92. Torti, N.; Walton, S.M.; Brocker, T.; Rülicke, T.; Oxenius, A. Non-hematopoietic cells in lymph nodes drive memory CD8 T cell inflation during murine cytomegalovirus infection. PLoS Pathog. 2011, 7, e1002313. [CrossRef] [PubMed]

93. Welten, S.P.M.; Baumann, N.S.; Oxenius, A. Fuel and brake of memory T cell inflation. Med. Microbiol. Immunol. 2019, 208, 329-338. [CrossRef] [PubMed]

94. Lemmermann, N.A.; Reddehase, M.J. Direct evidence for viral antigen presentation during latent cytomegalovirus infection. Pathogens 2021, 10, 731. [CrossRef]

95. Griessl, M.; Renzaho, A.; Freitag, K.; Seckert, C.K.; Reddehase, M.J.; Lemmermann, N.A. Stochastic episodes of latent cytomegalovirus transcription drive CD8 T-cell "memory inflation" and avoid immune evasion. Front. Immunol. 2021, 12, 668885 [CrossRef]

96. Gabel, M.; Baumann, N.S.; Oxenius, A.; Graw, F. Investigating the dynamics of MCMV-specific CD8+ T cell responses in individual hosts. Front. Immunol. 2019, 10, 1358. [CrossRef]

97. Snyder, C.M.; Cho, K.S.; Bonnett, E.L.; Allan, J.E.; Hill, A.B. Sustained CD8+ T cell memory inflation after infection with a single-cycle cytomegalovirus. PLoS Pathog. 2011, 7, e1002295. [CrossRef]

98. Gold, M.C.; Munks, M.W.; Wagner, M.; Koszinowski, U.H.; Hill, A.B.; Fling, S.P. The murine cytomegalovirus immunomodulatory gene $\mathrm{m} 152$ prevents recognition of infected cells by M45-specific CTL but does not alter the immunodominance of the M45-specific CD8 T cell response in vivo. J. Immunol. 2002, 169, 359-365. [CrossRef]

99. Holtappels, R.; Thomas, D.; Reddehase, M.J. The efficacy of antigen processing is critical for protection against cytomegalovirus disease in the presence of viral immune evasion proteins. J. Virol. 2009, 83, 9611-9615. [CrossRef] [PubMed]

100. Fink, A.; Lemmermann, N.A.; Gillert-Marien, D.; Thomas, D.; Freitag, K.; Böhm, V.; Wilhelmi, V.; Reifenberg, K.; Reddehase, M.J.; Holtappels, R. Antigen presentation under the influence of 'immune evasion' proteins and its modulation by interferon-gamma: Implications for immunotherapy of cytomegalovirus infection with antiviral CD8 T cells. Med. Microbiol. Immunol. 2012, 201, 513-525. [CrossRef]

101. Böhm, V.; Podlech, J.; Thomas, D.; Deegen, P.; Pahl-Seibert, M.F.; Lemmermann, N.A.; Grzimek, N.K.; Oehrlein-Karpi, S.A.; Reddehase, M.J.; Holtappels, R. Epitope-specific in vivo protection against cytomegalovirus disease by CD8 T cells in the murine model of preemptive immunotherapy. Med. Microbiol. Immunol. 2008, 197, 135-144. [CrossRef] [PubMed]

102. Lemmermann, N.A.; Gergely, K.; Böhm, V.; Deegen, P.; Däubner, T.; Reddehase, M.J. Immune evasion proteins of murine cytomegalovirus preferentially affect cell surface display of recently generated peptide presentation complexes. J. Virol. 2010, 84, 1221-1236. [CrossRef] 
103. Lučin, P.; Mahmutefendić, H.; Blagojević Zagorac, G.; Ilić Tomaš, M. Cytomegalovirus immune evasion by perturbation of endosomal trafficking. Cell. Mol. Immunol. 2015, 12, 154-169. [CrossRef] [PubMed]

104. Holtappels, R.; Schader, S.I.; Oettel, O.; Podlech, J.; Seckert, C.K.; Reddehase, M.J.; Lemmermann, N.A. Insufficient antigen presentation due to viral immune evasion explains lethal cytomegalovirus organ disease after allogeneic hematopoietic cell transplantation. Front. Cell. Infect. Microbiol. 2020, 10, 157. [CrossRef] [PubMed]

105. Gezinir, E.; Podlech, J.; Gergely, K.M.; Becker, S.; Reddehase, M.J.; Lemmermann, N.A. Enhancement of antigen presentation by deletion of viral immune evasion genes prevents lethal cytomegalovirus disease in minor histocompatibility antigen-mismatched hematopoietic cell transplantation. Front. Cell. Infect. Microbiol. 2020, 10, 279. [CrossRef]

106. Reddehase, M.J.; Holtappels, R.; Lemmermann, N.A. Consequence of histoincompatibility beyond GvH-reaction in cytomegalovirus disease associated with allogeneic hematopoietic cell transplantation: Change of paradigm. Viruses 2021, 13, 1530. [CrossRef] 